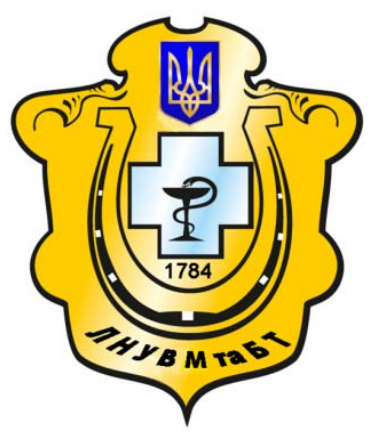

Науковий вісник Львівського національного університету ветеринарної медицини та біотехнологій імені С.3. Гжицького

Scientific Messenger of Lviv National University of Veterinary Medicine and Biotechnologies named after S.Z. Gzhytskyj

doi:10.15421/nvlvet7732

ISSN 2518-7554 print

ISSN 2518-1327 online

$\underline{\text { http://nvlvet.com.ua/ }}$

\title{
Моніторинг безпечності та якості продуктів забою свиней, отриманих в умовах Одеської області
}

\author{
М.С. Хімич, О.М. Горобей, Ф.В. Козулін, В.В. Жеков \\ khimichms@yandex.ua, gorobey@te.net.ua, fedotkozulin@gmail.com, fedyloffvictor@mail.ru \\ Одеський державний аграрний університет, \\ вул. Пантелеймонівська, 13, м. Одеса, 65012, Украӥна
}

\begin{abstract}
Відповідно до сучасних вимог міжнародної системи контролю (НАССР) необхідно відмовитися від контролю кіниевого продукту на предмет виявлення недоліків, а перейти на профілактичний підхід ліквідації потенційних джерел небезпеки на всіх ступенях виробництва. Ступенева система контролю якості продукиї тваринництва, зокрема м'яса, при відсутності сучасної технології первинної переробки і якісного ветеринарно-санітарного контролю складна. Тому для гарантії безпечності та якості м'яса необхідно удосконалювати і науково обтрунтовувати методику їх контролю, наближаючи ї до міжнародних вимог. Метою наших досліджень був моніторинг безпечності та якості продуктів забою свиней, отриманих в умовах Одеської області. Матеріалом досліджень була звітність з питань ветеринарної медицини (Форма № 6-вет, Форма № 5-вет, Форма № 2а-вет.) районів Одеської області за 2014-2016 роки, яку обробляли статистично. Проведений аналіз встановив, що за 2014-2016 рр. в досліджуваних районах було забито всього 28846 голів свиней, причому 74,48\% забою відбулось подвірно. Встановлено, мо за результатами передзабійного огляду і післязабійної ветсанекспертизи туш свиней за звітний період виявлено 83 випадки хвороб, а саме ехінококозу. За звітні роки на агропродовольчі ринки досліджуваних районів надійшло для реалізації 17103 туші свиней. Співробітниками ДЛВСЕ на ринках було проведено 65417 лабораторних досліджень: всі туші свиней було досліджено органолептично (в т. ч. пробою варки), проведено трихінелоскопію $i$ дослідження на фіноз та інші паразитарні захворювання; визначення фізико-хімічних показників $і$ бактеріоскопія туш проводились в окремих випадках; радіологічні та інші дослідження в звітному періоді не проводились. Під час ветеринарносанітарної експертизи в ДЛВСЕ на ринках було виявлено 662 випадки хвороб: 65 випадків незаразних і 597 випадків інвазійних хвороб. Причому звертає увагу, що 99,83\% виявлених інвазійних хвороб становив ехінококоз. Порівняльний аналіз результатів щуодо виявлення випадків ехінококозу залежно від місия проведення ветсанекспертизи встановив значні розбіжності - за післязабійної ветсанекспертизи виявляється лише 7,2-26,27\% випадків хвороби, порівняно з результатами ветеринарно-санітарної експертизи продуктів забою в ДЛВСЕ на ринках. Даний дисбаланс, на нашу думку, можна пов'язати 3 фактом подвірного забою і низькою якістю післязабійної ветсанекспертизи за таких умов.

Узагальнюючи отримані результати аналізу, можна зробити висновок, щчо система управління безпечністю і якістю продуктів забою свиней в районах Одеської області на сучасному етапі і досі спирається на аналіз кінцевого продукту, не враховуючи превентивного підходу.
\end{abstract}

Ключові слова: безпечність, якість, ветеринарно-санітарна експертиза, моніторинг, свині, продукти забою, ехінококоз, Одеська область.

\section{Мониторинг безопасности и качества продуктов убоя свиней, полученных в условиях Одесской области}

\author{
М.С. Химич, А.М. Горобей, Ф.В. Козулин, В.В. Жеков \\ khimichms@yandex.ua, gorobey@te.net.ua, fedotkozulin@gmail.com, fedyloffvictor@mail.ru \\ Одесский государственный аграрный университет, \\ ул. Пантелеймоновская, 13, г. Одеса, 65012, Украина
}

Citation:

Khimich, M.S., Gorobei, A.M., Kozulin, F.V., Zhekov, V.V. (2017). Monitoring of safety and quality products slaughter of pigs obtained in Odessa region. Scientific Messenger LNUVMBT named after S.Z. Gzhytskyj, 19(77), 148-152. 
В соответствии с современными требованиями международной системы контроля (НАССР) необходимо отказаться от контроля конечного продукта на предмет выявления недостатков, а перейти к профилактическому подходу ликвидации потенциальных источников опасности на всех ступенях производства. Ступенчатая система контроля качества продукции животноводства, в частности мяса, при отсутствии современной технологии первичной переработки и качественного ветеринарно-санитарного контроля сложная. Поэтому для гарантии безопасности и качества мяса необходимо совершенствовать и научно обосновывать методику их контроля, приближая ее к международным требованиям. Целью наших исследований был мониторинг безопасности и качества продуктов убоя свиней, полученньх в условиях Одесской области. Материалом исследований была отчетность по вопросам ветеринарной медицинь (Форма № 6-вет, Форма № 5вет, Форма № 2а-вет.) районов Одесской области за 2014-2016 годы, которую обрабатывали статистически. Проведенный анализ установил, что за 2014-2016 г2. в исследуемых районах было забито всего 28846 голов свиней, причем 74,48\% забоя состоялось подворно. Установлено, что по результатам предубойного осмотра и послеубойной ветсанэкспертизы туш свиней за отчетный период выявлено 83 случая заболеваний, а именно эхинококкоза. За отчетные годьл на агропродовольственные рынки исследуемых районов поступило для реализации 17103 туши свиней. Сотрудниками лабораторий ветеринарно-санитарной экспертизы на рынках было проведено 65417 лабораторных исследований: все туши свиней были исследованы органолептически (в т. ч. пробой варки), проведены трихинелоскопия и исследования на финоз и другие паразитарные заболевания; определения физико-химических показателей и бактериоскопия тушь проводились в отдельньх случаях; радиологические и другие исследования не проводились. Во время ветеринарно-санитарной экспертизы в лабораториях ветеринарно-санитарной экспертизы на рынках было выявлено 662 случая заболеваний: 65 случаев незаразных и 597 случаев инвазионных болезней. Причем обращает внимание, что 99,83\% выявленных инвазионных болезней составил эхинококкоз. Сравнительный анализ результатов по выявлению случаев эхинококкоза в зависимости от места проведения ветсанэкспертизы установил значительные расхождения - при послеубойной ветсанэкспертизе выявляется только 7,2626,27\% случаев болезни, по сравнению с результатами ветеринарно-санитарной экспертизы продуктов убоя в лабораториях ветеринарно-санитарной экспертизы на рынках. Данный дисбаланс, по нашему мнению, можно связать с подворныл убоем и низким качеством послеубойной ветсанэкспертизы в таких условиях.

Обобщая полученные результаты анализа, можно сделать вывод, что система управления безопасностью и качеством продуктов убоя свиней в районах Одесской области на современном этапе до сих пор опирается на анализ конечного продукта, не учитьвая превентивного подхода.

Ключевые слова: безопасность, качество, ветеринарно-санитарная экспертиза, мониторинг, свиньи, продукть убоя, эхинококкоз, Одесская область.

\title{
Monitoring of safety and quality products slaughter of pigs obtained in Odessa region
}

\author{
M.S. Khimich, A.M. Gorobei, F.V. Kozulin, V.V. Zhekov \\ khimichms@yandex.ua, gorobey@te.net.ua, fedotkozulin@gmail.com, fedyloffvictor@mail.ru
}

\author{
Odessa State Agrarian University, \\ Panteleimonovskaya Str., 13, Odessa, 65012, Ukraine
}

In accordance with the modern requirements of the international control system (HACCP), it is necessary to abandon the control of the final product for the purpose of identifying shortcomings, but to proceed to the preventive approach of eliminating potential sources of danger at all stages of production. A step-by-step system for controlling the quality of livestock products, in particular meat, in the absence of modern technology of primary processing and quality veterinary and sanitary control, is complex. Therefore, to ensure the safety and quality of meat, it is necessary to improve and scientifically justify the methods of their control, bringing it closer to international requirements. The purpose of our research was to monitor the safety and quality of slaughter products for pigs obtained in the conditions of the Odessa region. The material of the research was reporting on veterinary medicine (Form No. 6-vet., Form No. 5-vet., Form No. 2a-vet.) In the districts of the Odessa region for 2014-2016, which was processed statistically. The analysis has established that for 2014-2016. In the investigated areas, only 28846 pigs were slaughtered, and $74.48 \%$ of the slaughter took place. It was found that according to the results of the pre-blast inspection and post-mortem veterinary examination of pig carcasses, 83 cases of diseases, echinococcosis, were detected during the reporting period. For the reporting years, 17103 carcasses of pigs were supplied to the agro-food markets of the study areas. Employees of laboratories for veterinary and sanitary examination in the markets conducted 65417 laboratory studies: all carcasses of pigs were examined organoleptically (including cooking breakdown), trichinoscopy and studies for phychosis and other parasitic diseases were performed; The determination of physicochemical parameters and bacterioscopy of mascara were carried out in individual cases; radiological and other studies were not conducted. During the veterinary and sanitary examination, 662 cases of diseases were detected in the laboratories of veterinary and sanitary examination in the markets: 65 cases of non-communicable diseases and 597 cases of invasive diseases. And draws attention to the fact that $99.83 \%$ of the identified invasive diseases was echinococcosis. Comparative analysis of the results on the detection of cases of echinococcosis, depending on the location of Veterinary control, found significant discrepancies-after postmortem veterinary and sanitary control, only 7.26-26.27\% of cases are detected, in comparison with the results of veterinary and sanitary examination of slaughter products in laboratories for veterinary and sanitary examination In the markets. This imbalance, in our opinion, can be related to homestead slaughter and poor quality post-mortem Veterinary control during it.

Summarizing the obtained results of the analysis, we can conclude that the management system for the safety and quality of slaughter products in pigs in the regions of the Odessa region at the present stage still relies on the analysis of the final product, not taking into account the preventive approach.

Key words: safety, quality, veterinary and sanitary examination, monitoring, pigs, slaughter products, echinococcosis, Odessa region. 


\section{Вступ}

Державний ветеринарно-санітарний контроль і нагляд повинні не тільки забезпечити випуск продуктів високої санітарно-гігієнічної якості, а й гарантувати охорону населення від хвороб, спільних для тварин і людей (Muharovs'kyj, 2001; Podrushnjak et al., 2002).

Чинна в Україні система контролю якості м'яса та м'ясопродуктів, що була налагоджена і діяла, - дослідження зразків кінцевих продуктів, перевірка санітарно-гігієнічних показників переробних підприємств і торгових точок, вилучення з виробництва сировини, а з торгівлі - готової продукції, яка становить небезпеку, та притягнення до відповідальності осіб, що допустили виробництво і реалізацію неякісної продукції, в сучасних умовах стала малоефективною і не спроможна гарантувати безпеку і якість продукції тваринництва, тому що не враховує превентивного аспекту (Poltavchenko, 2000).

Тому в торгову мережу, особливо на ринках, часто потрапляють м'ясо та м'ясопродукти низької санітарної якості, які можуть бути джерелом харчових токсикозів, токсикоінфекцій та інших захворювань у людей.

Відповідно до сучасних вимог міжнародної системи контролю (НАССР) необхідно відмовитися від контролю кінцевого продукту на предмет виявлення недоліків, а перейти на профілактичний підхід ліквідації потенційних джерел небезпеки на всіх ступенях виробництва (DSTU 4161-2003; Jakubchak and Mel'nichuk, 2004; Jakubchak, 2011).

При розробці моніторингу якості та безпеки м'яса варто використовувати результати наукових досліджень, враховуючи, що продукти забою, які надходять на реалізацію на агропромислові ринки, можуть становити небезпеку і ризики (Poltavchenko, 2000; Jakubchak, 2011).

Ступенева система контролю якості продукції тваринництва, особливо м'яса, яке отримують в приватних та фермерських господарствах, при відсутності сучасної технології первинної переробки і ветеринарно-санітарного контролю, складна. Тому для визначення санітарної якості м'яса в умовах ДЛВСЕ необхідно удосконалювати і науково обгрунтовувати методику контролю якості та безпеки м'яса, наближаючи ii до міжнародних вимог (Poltavchenko, 2000; Jakubchak, 2011).

Враховуючи актуальність цього питання, була поставлена мета: провести моніторинг безпечності та якості продуктів забою свиней, отриманих в умовах Одеської області.

\section{Матеріал і методи досліджень}

Дослідження проводилось на базі трьох районів Одеської області - Березівського, Роздільнянського і Саратського.

Матеріалом наших досліджень була звітність 3 питань ветеринарної медицини (Форма № 6-вет, Форма № 5-вет, Форма № 2а-вет.) за 2014-2016 роки зазначених районів.

Звітну документацією 3 питань ветеринарної медицини ми обробляли статистично.

\section{Результати та їх обговорення}

На початку дослідження ми проаналізували об'єми забою свиней. Встановлено (рис. 1), що за 20142016 pр. в районах було забито всього 28846 голів свиней. Вірогідної тенденції щодо змін кількості забитих голів в цей період не виявлено.

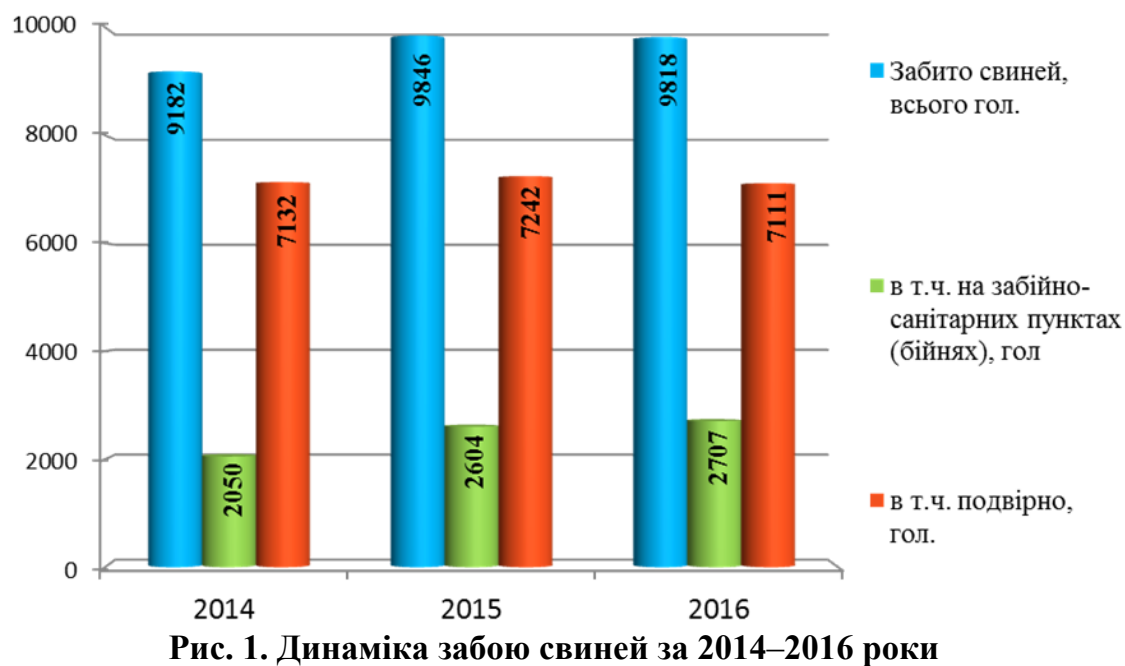

3 рисунка 1 видно, що в звітний період більшість забою - 74,48\%, відбувалась подвірно, хоча і спостерігається незначна динаміка зростання кількості забоїв на забійно-санітарних пунктах. Тут важливо зазначити, що згідно $з$ даними звітності (Форма № 6-вет) забійно-санітарні пункти функціонують лише на території Саратського району, а в Березівському і Роздільнянському - відсутні.
Зважаючи на те, що згідно 3 «Ветеринарносанітарними правилами для боєнь, забійно-санітарних пунктів господарств та подвірного забою тварин» забій тварин допускається тільки за умови проведення передзабійного огляду і післязабійної ветсанекспертизи, надалі ми проаналізували результати ветеринарносанітарного контролю і нагляду при забої свиней за 2014-2016 роки (рис. 2). 


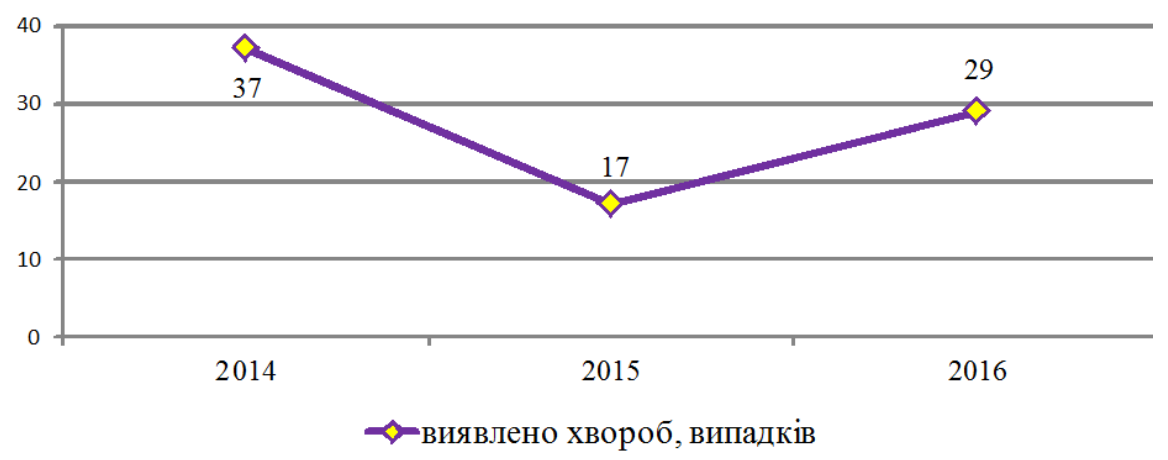

\section{Рис. 2. Динаміка виявлення хвороб за результатами передзабійного огляду і післязабійної ветсанекспертизи за 2014-2016 роки}

Встановлено, що за звітний період виявляли 83 випадки хвороб тварин і всі випадки - це інвазійні хвороби, а саме ехінококоз.

Звертаємо увагу, що кількість виявлених випадків хвороб загалом не мала чіткої динаміки. Окремо зазначимо, що кількість виявлення хвороб значно різнилась залежно від району. Так, лише в районі, де щороку зростає відсоток забою свиней на бойнях, спостерігається динаміка зростання виявлення випадків хвороб, що можна пов'язати з більш високою якістю проведення післязабійної ветсанекспертизи в умовах бійні.

Надалі ми проаналізували об'єм надходження продуктів забою свиней для реалізації на агропродо- вольчі ринки районів і результати їх ветеринарносанітарної експертизи в умовах ДЛВСЕ на ринках за 2014-2016 роки (рис. 3).

3 рисунку 3 видно, що за звітні роки на агропродовольчі ринки районів надійшло для реалізації 17103 туші свиней, що становить 59,29\% забитих за цей період голів свиней. Таким чином, можна зробити висновок, що решта продуктів забою реалізується за межами районів, наприклад на ринках м. Одеси.

Також спостерігаємо тенденцію щодо зниження кількості продуктів забою, що надходять у реалізацію, - 34,05\% у 2014 році, 33,33\% у 2015 році та 32,61 у 2016 році відносно загальної кількості продукції.

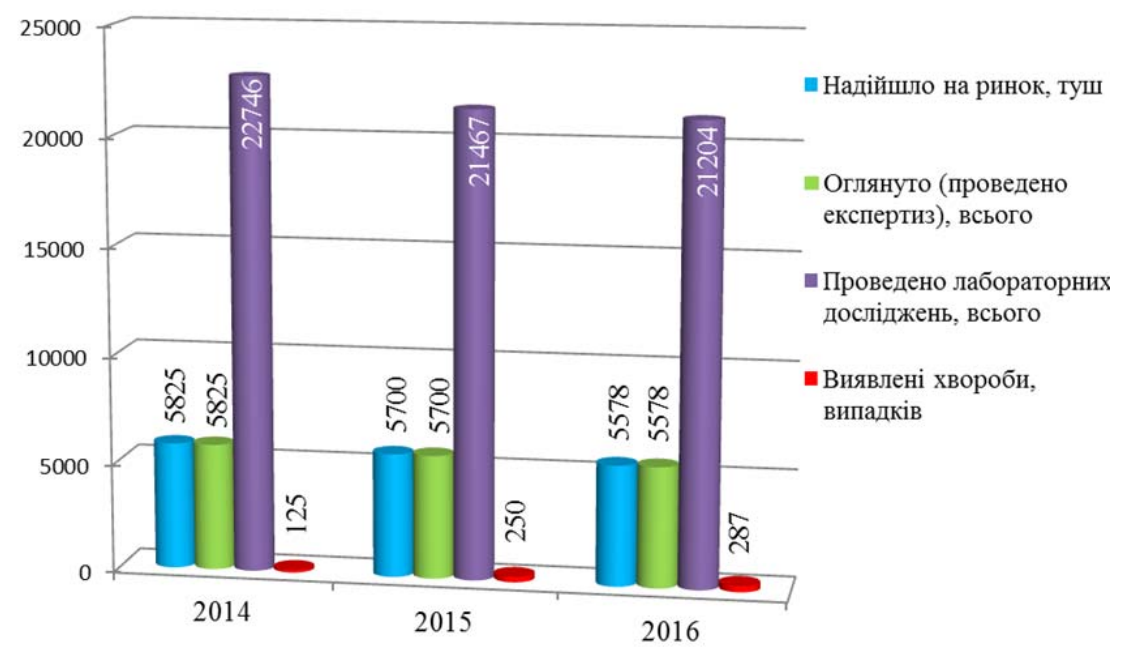

Рис. 3. Динаміка реалізації та проведення ветсанекспертизи продуктів забою свиней в ДЛВСЕ на ринках за 2014-2016 роки

Згідно зі звітністю (Форма № 5-вет) спеціалістами ДЛВСЕ на ринках було оглянуто всі 17103 туш свиней, які надійшли для реалізації. Щодо проведення лабораторних досліджень, то було проведено всього 65417 дослідження. Згідно з даними (Форма № 2а-вет) встановлено, що всі туші свиней які надійшли для реалізації, було досліджено органолептично, в т. ч. пробою варки, проведено трихінелоскопію і дослідження на фіноз та інші паразитарні захворювання; визначення фізико-хімічних показників і бактеріоско- пія туш проводились не завжди, а, як можна припустити, лише в сумнівних випадках; радіологічні та інші дослідження в звітному періоді взагалі не проводились.

I хоча отримані дані не суперечать нормам законодавства, постає питання, чи можна вважати ветеринарно-санітарну експертизу продуктів забою в ДЛВСЕ на ринках такою, що повністю гарантує безпечність та якість цих продуктів для населення. Адже така систе- 
ма аналізу не забезпечує виявлення всіх ризиків (наприклад, антибіотиків) для споживача.

Щодо виявлення хвороб за результатами ветсанекспертизи на ринках, то з рисунку 3 видно, що за період 2014-2016 років було виявлено всього 662 випадки хвороб. Простежується динаміка зростання кількості виявлення випадків хвороб: у 2014 році - 18,88\%, у 2015 - 37,76\% і у 2016 - 43,35\% від загальної кількості виявлених у досліджуваний період. Що ж стосується етіології виявлених хвороб, то за звітний період фахівцями ДЛВСЕ на ринку випадків інфекційних хвороб не зареєстровано, зафіксовано 65 випадків незаразних і 597 випадків інвазійних хвороб. Причому звертає увагу, що 99,83\% виявлених інвазійних хвороб становив ехінококоз.
Надалі, враховуючи отримані результати і з уваги на небезпеку ехінококозу для людини, ми провели порівняльний аналіз результатів передзабійного огляду та післязабійної ветсанекспертизи свиней і результатів ветеринарно-санітарних експертиз продуктів забою свиней на ринках (рис. 4).

3 рисунку 4 видно, що за період 2014-2016 років під час післязабійної ветсанекспертизи при забої свиней кількість випадків виявлення ехінококозу є значно нижчою, ніж при проведенні ветеринарносанітарної експертизи продуктів забою свиней в ДЛВСЕ на ринках - у 2014 році - 26,27\%, у 2015 7,26\% і у 2016 році - 11,89\% від кількості випадків виявлення в умовах ДЛВСЕ на ринках.

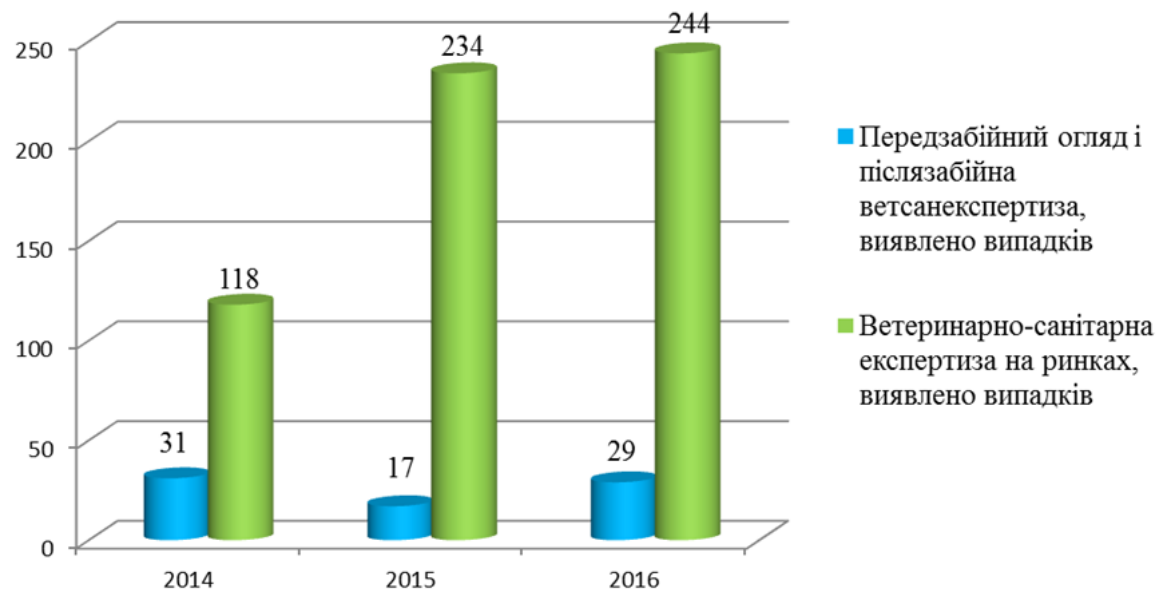

Рис. 4. Динаміка виявлення ехінококозу залежно від місця проведення досліджень за $2013-2015$ роки

Даний дисбаланс, на нашу думку, можна пов'язати 3 фактом подвірного забою і низькою якістю післязабійної ветсанекспертизи за таких умов.

\section{Висновки}

Узагальнюючи отримані результати, на жаль, можна зробити висновок, що чинна система управління безпечністю і якістю продуктів забою свиней в районах Одеської області й досі спирається на аналіз кінцевого продукту, не враховуючи превентивного підходу i, як наслідок, не може повною мірою гарантувати безпечність продуктів забою для споживачів.

Перспективи подальших досліджень. Статистичний аналіз звітності з питань ветеринарної медицини дозволить сформувати загальне уявлення щодо обігу продуктів забою тварин - виявити закономірності і особливості проведення забою, первинної переробки і реалізації продукції тваринництва та їх динаміку. Це дозволить чітко означити основні проблемні ланки системи управління безпечністю і якістю продуктів та сприятиме їх вирішенню.

\section{Бібліографічні посилання}

Muharovs'kyj, M. (2001). Systema bezpeky harchovyh produktiv. Standartyzacija, sertyfikacija, jakist'. 4, 55-56 (in Ukrainian).

Podrushnjak, A.Je., Voloshhenko, Z.L., Capko, O.V. (2002). Sanitarno-gigijenichni vymogy do jakosti i bezpeky m'jasa i m'jasnyh produktiv. M'jasnyj biznes. 1, 44-46 (in Ukrainian).

Poltavchenko, T. (2000). Suchasni pravovi j normatyvni aspekty veterynarno-sanitarnoi' ekspertyzy na rynkah. Veterynarna medycyna Ukrai'ny. 6, 41 (in Ukrainian).

Systemy upravlinnja bezpechnistju harchovyh produktiv (DSTU 4161-2003). [chynnyj vid 01.07.2003]. K.: Derzhspozhyvstandart Ukrai'ny, 2003. 61 (Nacional'nyj standart Ukrai'ny).

Jakubchak, O.N., Mel'nichuk, S.I. (2004). HACCP jeffektivnaja preventivnaja sistema garantii bezopasnosti produktov pitanija. Mjasnoj biznes. $7(25), 68-69$.

Jakubchak, O.M. (2011). Suchasni pidhody do zabezpechennja bezpechnosti m'jasa V Ukrai'n. M'jasni tehnologii' svitu. 7, 34-36.

Стаття надійшла до редакиії 20.03.2017 